\title{
$\frac{100}{\text { LAT }}$ RPEiS
}

\author{
MACIEJ ŻUKOWSKI*
}

\section{AKTUALNE PROBLEMY CZASOPISM NAUKOWYCH W POLSCE}

\section{WSTĘP}

Stulecie „Ruchu Prawniczego, Ekonomicznego i Socjologicznego”, jednego z najstarszych i najbardziej prestiżowych czasopism naukowych w Polsce, jest świetna okazją do podjęcia refleksji na temat aktualnych problemów polskich czasopism naukowych. Krytycznej analizie poddane zostaną wybrane kwestie dotyczace czasopism naukowych w Polsce: waga artykułów w czasopismach wobec książek, listy czasopism i punkty, preferowanie czasopism w języku angielskim, przypisanie dyscyplin do czasopism, otwarty dostęp, drapieżne czasopisma. Artykuł kończą refleksje na temat przyszłości czasopism naukowych w Polsce.

Artykuł podejmuje wymienione kwestie w odniesieniu do nauk społecznych i humanistycznych, w tym głównie nauk ekonomicznych, a przede wszystkim - według aktualnej klasyfikacji dyscyplin naukowych w Polsce dyscypliny ekonomia i finanse ${ }^{1}$.

\section{ARTYKULY W CZASOPISMACH A MONOGRAFIE NAUKOWE}

Truizmem jest stwierdzenie, że bez czasopism naukowych nie można sobie wyobrazić współczesnej nauki. „Dzisiejsza nauka jest zorientowana na publikacje”2,

* Maciej Żukowski, Rektor Uniwersytetu Ekonomicznego w Poznaniu, maciej.zukowski@ue.poznan.pl, https://orcid.org/0000-0003-0551-7458.

${ }^{1}$ Do roku 2018 w polskiej klasyfikacji dziedzin i dyscyplin naukowych wyróżniano dziedzinę nauk ekonomicznych. Według rozporządzenia, które weszło w życie 1 października 2018 r., w ramach dziedziny nauk społecznych wyróżnia się m.in. dyscypliny ekonomia $i$ finanse oraz nauki o zarzadzaniu i jakości. O problemach klasyfikacji nauk ekonomicznych por. Gorynia (2019).

${ }^{2}$ Kulczycki (2019): 159. 
a podstawowym narzędziem komunikacji naukowej stały się właśnie czasopisma naukowe. Watpliwości podnoszone są natomiast niekiedy wobec preferowania $\mathrm{w}$ formalnych systemach ewaluacji artykułów w czasopismach wobec rozdziałów w ksiażkach czy całych monografii.

W rozporządzeniu Ministra Nauki i Szkolnictwa Wyższego z 22 lutego 2019 r. w sprawie ewaluacji jakości działalności naukowej ${ }^{3}$ uznaje się znaczenie monografii naukowych i rozdziałów w monografiach naukowych w trzech dziedzinach nauk: humanistycznych, społecznych i teologicznych. Takie preferencje dla tych dziedzin są wyrazem uznania, że w naukach humanistycznych i społecznych to właśnie monografie są wyjątkowo ważnym miejscem publikacji naukowych ${ }^{4}$. Generalnie jednak decydujące znaczenie przypisuje się publikacjom w czasopismach naukowych, zwłaszcza międzynarodowych.

Analiza publikacji polskich naukowców z lat 2013-2016 pokazuje, że naukowcy publikujacy w monografiach są bardziej „produktywni” (publikuja więcej) oraz że publikują także artykuły naukowe, ale częściej w czasopismach o lokalnym charakterze. Polscy naukowcy publikują monografie znacznie częściej niż na przykład norwescy (w naukach społecznych: 45,5\% naukowców opublikowało monografię w Polsce i 8,5\% w Norwegii, a w humanistycznych odpowiednio $49,5 \%$ i $15,7 \%)^{5}$. Tak znaczacy odsetek reprezentantów tych dziedzin nauki w Polsce publikujących monografie wynika między innymi z dominującego dotąd wzorca habilitacji. W latach 2011-2016 mniej niż 2\% naukowców w Polsce z nauk chemicznych i farmaceutycznych opublikowało monografię dla celów habilitacyjnych, podczas gdy w naukach społecznych i humanistycznych było to ponad $70 \%{ }^{6}$.

W zakresie uwzględniania monografii i rozdziałów w monografiach naukowych w stosunku do artykułów w czasopismach naukowych obecne polskie rozwiązania wydają się $\mathrm{w}$ dostatecznym stopniu uwzględniać specyfikę nauk społecznych i humanistycznych. W tych naukach książki (monografie) były i są bardzo ważnym kanałem komunikacji. Nie powinny być traktowane jako „druga kategoria”, przy czym oczywiście duże znaczenie mają prestiż i zasięg wydawnictwa.

Należy spodziewać się wzrostu znaczenia publikacji w czasopismach naukowych, zwłaszcza międzynarodowych, także w naukach ekonomicznych, $\mathrm{w}$ tym dla celów habilitacji. $\mathrm{W}$ odniesieniu do nauk ekonomicznych byłaby to zapewne pozytywna zmiana, publikacje w monografiach miały bowiem dotąd często tylko lokalny zasięg, nie wchodziły do szerszego obiegu naukowego, były rzadziej cytowane niż publikacje w czołowych czasopismach naukowych.

Odrębną kwestia, wykraczająca poza ramy tego artykułu, są natomiast wyzwania stojące przed autorami i wydawcami ksiazzek naukowych i możliwe

\footnotetext{
${ }^{3}$ Dz. U. 2019, poz. 392.

${ }^{4}$ Giménez-Toledo, Román-Román (2009).

${ }^{5}$ Kulczycki, Korytkowski (2019): 1385.

${ }^{6}$ Kulczycki, Korytkowski (2019): 1385.
} 
kierunki zmian w tym zakresie. Część problemów jest wspólna dla książek naukowych i czasopism naukowych, jak punktacja, otwarty dostęp czy język publikacji?.

\section{WĄTPLIWOŚCI WOBEC LIST CZASOPISM I PUNKTÓW}

Poczatki bibliometrii umieszcza się z reguły w latach pięćdziesiątych i sześćdziesiątych XX w., choć wskazuje się na pierwsze opracowania z tego zakresu już z początku $\mathrm{XX}^{8}$.

Bibliometria i naukometria sa zapewne przejawem ogólniejszych tendencji we współczesnym świecie. „Funkcjonujemy w rzeczywistości społecznej poddawanej nieznośnemu dyktatowi policzalności wszystkiego. Wartość i znaczenie ma jedynie to, co jest lub może być mierzalne. Kwantyfikacja stała się naszym fetyszem, bez którego nie wyobrażamy sobie życia we współczesnym świecie"'.

Jest to ogólna tendencja, choć rozwiązania różnią się pomiędzy państwami. Przykładem bardzo rozbudowanego systemu ujęcia publikacji naukowych za pomoca jednego wskaźnika, pozwalającego porównać efekty badań naukowych w ramach i pomiędzy instytucjami badawczymi jest „model norweski”, zastosowany także w innych państwach: Belgii (Flandria), Danii, Finlandii i Portugalii, a także lokalnie w kilkunastu uczelniach w Szwecji ${ }^{10}$.

W Polsce także stosunkowo długo już funkcjonuje rozwiazanie „parametryczne” (a nie „oceny eksperckiej”) w formie ministerialnej listy czasopism naukowych z punktami przypisanymi do czasopisma. W przygotowanie listy w roku 2019, pierwszej po przyjęciu nowej ustawy, zaangażowani byli eksperci w 44 zespołach dokonujacych oceny w poszczególnych dyscyplinach nauki, na tej podstawie Komisja Ewaluacji Nauki (KEN) przygotowała wykaz ${ }^{11}$. Ostatecznie lista jest ogłaszana komunikatem ministra - najnowsza, przygotowana z pominięciem KEN, komunikatem Ministra Edukacji i Nauki z 9 lutego 2021 r., następnie zmieniona komunikatem z 18 lutego 2021 r.

Każdy artykuł w danym czasopiśmie otrzymuje tę samą liczbę punktów. W uzasadnieniu projektu rozporządzenia Ministra Nauki i Szkolnictwa Wyższego z 7 listopada 2018 r. w sprawie sporządzania wykazów wydawnictw monografii naukowych oraz czasopism naukowych i recenzowanych materiałów z konferencji międzynarodowych ${ }^{12}$ mowa jest o przyjęciu „zasady dziedziczenia prestiżu wydawnictwa lub czasopisma, polegającej na tym, że artykuł naukowy jest wart tyle, ile czasopismo, w którym jest opublikowany". Zasada dziedziczenia prestiżu jest dyskusyjna i było wielokrotnie poddawana krytyce ${ }^{13}$.

\footnotetext{
7 Por. m.in. Breczko (2016).

8 Godin (2017).

9 Szpunar (2019): 95.

10 Sivertsen (2017).

11 Hintz et al. (2019); Skoczeń (2019).

12 Dz. U. 2018, poz. 2152.

13 Zob. m.in. Wróblewski (2018); Kokowski (2018): 459.
} 
Punktacja czasopism ma być odzwierciedleniem istniejącego zjawiska zróżnicowania, rozwarstwienia prestiżu ${ }^{14}$. Tak uzasadniane są bardzo duże różnice w liczbie przyznawanych czasopismom punktów - obecnie na ministerialnej liście jest to od 20 do 200 pkt. Ministerstwo deklarowało dążenie do ograniczenia punktozy, jak nazywana jest strategia gromadzenia wielu nisko punktowanych (a więc w założeniu: nisko prestiżowych) artykułów. Pożądana ma być strategia publikowania artykułów w najlepszych czasopismach. W skrajnej wersji, w której naukowiec zakłada tylko takie publikacje, mamy do czynienia z impaktoza (impactitis): liczą się tylko artykuły z wysokim impact factor ${ }^{15}$.

Podstawowe kryteria, od których zależy liczba przyznanych punktów, zostały sformułowane, pozostawiając jednak nadal duże pole uznaniowości. Nawet jeżeli przyjmie się do wiadomości konieczność tego rodzaju kwantyfikacji, trudno często zrozumieć ministerialne rozstrzygnięcia. Tylko tytułem przykładu z zakresu nauk ekonomicznych: dlaczego „Ekonomista” ma (tylko) 40 pkt, nie jest jasne. Wątpliwości budziła każda lista ${ }^{16}$, natomiast wyjątkowe wywołała najnowsza, z lutego 2021 r., na której znalazły się nowe czasopisma, a wcześniej już na niej umieszczone uzyskały niekiedy zaskakująco wysoka punktację. Przykładowo, „Ruch Prawniczy, Ekonomiczny i Socjologiczny” uzyskał ponownie $40 \mathrm{pkt}$, natomiast „Biuletyn Stowarzyszenia Absolwentów i Przyjaciół Wydziału Prawa Katolickiego Uniwersytetu Lubelskiego" - 70 pkt (poprzednio: 20). Taka uznaniowość ministra narusza zaufanie do tego rozwiąania i bardzo wzmacnia wszystkie wątpliwości zgłaszane wobec takiego sposobu kwantyfikacji osiagnięć naukowych.

Niezależnie bowiem od konkretnych rozwiązań zasada publish or perish wzbudza kontrowersje w każdym kraju. Dla przykładu, z opublikowanych właśnie wyników badań wynika, że dwie trzecie ekonomistów pracujących na uniwersytetach w Holandii uznało, że zasada ta ma, oprócz plusów, także poważne negatywne skutki ${ }^{17}$.

Wielu badaczy poddaje cały ten system zasadniczej krytyce: „Uprawianie nauki zostało zastapione gromadzeniem punktów. Nieustanne, dokonywane w krótkich okresach, rankingi osób, wydziałów i uniwersytetów nie sprzyjaja realizacji pasji i zainteresowań naukowych, bowiem "wszyscy» znajdują się pod presją zdobywania punktów oraz zwiększenia efektywności w tym zakresie. Rolę głównego "klasyfikatora" oraz konstruktora wskaźników odgrywa przy tym ministerstwo, które wyznaczając odgórnie reguły "parametryzacyjnej gry«, zmienia tożsamość (szczególnie młodych) naukowców"18.

Zdecydowaną krytykę sformułował niedawno wybitny polski ekonomista: „W rezultacie rodzi się "przemysł produkowania publikacji» nakierowanych

${ }^{14} \mathrm{~W}$ odniesieniu do badań nad szkolnictwem wyższym i najbardziej prestiżowymi czasopismami z tego zakresu - zob. Kwiek (2019a).

15 Kulczycki (2017).

${ }_{16}$ Tylko tytułem przykładu kontrowersji po ogłoszeniu listy w 2019 r. - w odniesieniu do nauk politycznych: Bäcker (2019).

17 Van Dalen (2021).

18 Melosik (2016): 248. 
na zdobywanie punktów, a nie przesuwanie granic wiedzy, nauki i wzbogacanie dorobku intelektualnego. Żeruja na tym międzynarodowe firmy (wydawnictwa) o bardzo podejrzanym rodowodzie i jakości. W kraju trwa konkurencja, oparta jednak na wątpliwych zasadach, o bardzo ograniczone środki przeznaczone na wspieranie badań i kształcenia. Ten proces czeka jeszcze na pogłębioną diagnozę i ocenę, ale powody do zaniepokojenia lawinowo narastają. Nie dążenie do prawdy, wzbogacanie mądrości, przesuwanie granic poznania, kształcenie elit i inne cele zawarte w misjach uniwersytetów i jednostek badawczych są najważniejsze, ale efekty rywalizacji zawarte w urzędowych algorytmach oceny nauki i naukowców"19.

Surowa jest też ocena Noblistki: „Uczeni, rywalizując o granty i punkty, zmienili się we współzawodniczących ze sobą wyrobników”20.

Te rozważania nie prowadzą do jasnej konkluzji. Z jednej strony przekonujące zdają się argumenty, że potrzebne sa sposoby pomiaru efektów pracy naukowców, także dla oceny „zwrotu” z inwestycji publicznych pieniędzy w naukę. Z drugiej jednak - takie sformalizowane biurokratyczne systemy grożą wypaczeniem roli nauki i naukowców. Zapewne potrzebne jest poszukiwanie jakiegoś kompromisu, aby pogodzić zalety konkurencji dla rozwoju nauki z wolnością badań naukowych i uprawiających je badaczy, a także z rola nauki wobec społeczeństwa.

\section{POŻĄDANA RÓWNOWAGA MIĘDZY CZASOPISMAMI W JĘZYKU POLSKIM A MIĘDZYNARODOWYMI CZASOPISMAMI W JĘZYKU ANGIELSKIM}

Nauka jest jedna, jest światowa, a współczesną łacina jest język angielski - to kolejne truizmy. Sa silne argumenty za publikowaniem w języku angielskim, gdyż tylko w ten sposób osiąnięcia badawcze mogą wejść do światowego obiegu naukowego. Preferowanie publikacji w języku angielskim występuje na całym świecie.

Jednak, przynajmniej w odniesieniu do nauk humanistycznych i społecznych, zasadne jest pytanie, czy publikacje w tych naukach, dotyczacych kultury i społeczeństwa, nie powinny również, a może przede wszystkim, ukazywać się w językach narodowych. Tym bardziej że nauka nie jest „dla siebie”, tylko powinna wywierać wpływ na funkcjonowanie społeczeństwa.

Studium porównawcze siedmiu państw europejskich, w tym Polski, potwierdza, że w naukach społecznych i humanistycznych naukowcy publikuja w swoich językach, nie tylko w języku angielskim ${ }^{21}$. Autorzy tego studium opowiadają się za równowaga pomiędzy międzynarodową doskonałościa (international excellence) i lokalnym znaczeniem (local relevance) badań naukowych.

\footnotetext{
19 Wilkin (2020): 94-95.

20 Tokarczuk (2020): 26.

21 Kulczycki et al. (2020).
} 
Odwołują się do Helsińskiej inicjatywy na rzecz wielojęzyczności w komunikacji naukowej22.

W tym kontekście można postawić pytanie, czy uzasadniona jest aż tak znaczna różnica między punktacją najlepszych czasopism w języku polskim a najlepszymi czasopismami w języku angielskim. Obecnie najwyżej punktowane czasopisma polskie w dyscyplinie ekonomia $i$ finanse maja 70 pkt, a najwyżej punktowane czasopisma zagraniczne (międzynarodowe) - 200 pkt.

Trudno nie zgodzić się z argumentami za koniecznością wspierania w polskiej polityce naukowej najlepszych naukowców współpracujących z zagranicą i publikujących w najlepszych międzynarodowych czasopismach. Jednakże w naukach społecznych i humanistycznych „miejscowi” są niezbędni tak, jak „internacjonaliści” ${ }^{23}$, a w konsekwencji czasopisma w języku polskim są konieczne do wypełnienia przez te nauki ich cywilizacyjnej roli.

Jednak potrzebne sa zmiany w polskich czasopismach naukowych. Jest ich bardzo dużo, często o bardzo małym zasięgu i oddziaływaniu. Celowe jest kontynuowanie wspierania jakości, promowania dobrych czasopism o zasięgu ogólnopolskim ${ }^{24}$.

\section{WĄTPLIWOŚCI WOBEC PRZYPISANIA DYSCYPLIN NAUKOWYCH DO CZASOPISM}

Nowym elementem na ministerialnych listach czasopism, wprowadzonym w ramach reformy $2.0 \mathrm{z} 2018$ r., jest przypisanie do czasopism dyscyplin naukowych. Dla przykładu, na liście z 18 lutego 2021 r. do „Ruchu Prawniczego, Ekonomicznego i Socjologicznego" przypisane są trzy dyscypliny: ekonomia $i$ finanse, nauki prawne i nauki socjologiczne. Z jednej strony przypisanie tych akurat dyscyplin wydaje się oczywiste, co wynika już z samego tytułu czasopisma. Jednakże powstaje pytanie o sens tego rozwiąania. W czasopiśmie publikowane sa też artykuły naukowców reprezentujących inne, pokrewne dyscypliny, tylko tytułem przykładu: nauki o polityce $i$ administracji, nauki o zarzadzaniu $i$ jakości, geografia społeczno-ekonomiczna $i$ gospodarka przestrzenna, historia. Wprawdzie zasady ewaluacji przewidują uznanie publikacji autora związanego z dyscyplina, która nie jest przypisana do danego czasopisma, o ile da się to uzasadnić, to jednak „tłumaczenie się” z publikacji w czasopiśmie nie ze „swojej” dyscypliny jest co najmniej krępujące. Czy to kolejne biurokratyczne ograniczenie nie jest przejawem braku zaufania ustawodawcy do naukowców?

Podobnie jak omawiana wcześniej punktacja, także to przypisanie dyscyplin budzi często kontrowersje. Przykładowo tylko z obszaru moich zainteresowań badawczych, pominięcie na liście z 18 lutego 2021 r. przypisania do

$22<$ https://www.helsinki-initiative.org/pl>

23 Kwiek (2019b).

${ }^{24} \mathrm{~W}$ odniesieniu do nauk humanistycznych - zob. Drabek, Bemke-Świtilnik (2020). 
czasopisma „Journal of Social Policy” dyscypliny ekonomia $i$ finanse jest ewidentnym błędem, podobnie jak brak tej dyscypliny przy polskim czasopiśmie „Polityka Społeczna”. W moim przekonaniu najlepiej byłoby całkowicie zrezygnować z przypisywania dyscyplin do czasopism.

Wielodyscyplinarność (jak w „Ruchu Prawniczym, Ekonomicznym i Socjologicznym”) jest zaleta. Do „Science” (za 200 pkt) na liście z 18 lutego 2021 r. przypisano 24 dyscypliny (ponownie nie wiadomo dlaczego bez ekonomicznych, chociaż są nauki prawne i nauki o bezpieczeństwie), a 23 do „Nature” (też za 200 pkt; tutaj sa nauki o zrzadzaniu i jakości, nie ma ekonomii i finansów, choć są nauki socjologiczne i nauki prawne).

\section{WĄTPLIWOŚCI WOBEC OTWARTEGO DOSTĘPU}

Otwarty (bezpłatny) dostęp do publikacji naukowych jest przeważnie uzasadniany tym, że całe społeczeństwo powinno móc korzystać z wyników badań finansowanych ze środków publicznych. Skoro wszyscy podatnicy zapłacili za badania naukowe, powinni mieć bezpłatny dostęp do ich wyników. Jest to przedstawiane jako realizacja zasady sprawiedliwości.

Ale przecież „nie ma czegoś takiego jak darmowy obiad”. Ktoś musi zapłacić za opublikowanie artykułu, wydanie czasopisma i jego dystrybucję. Skoro czasopismo jest dostępne za darmo, przeważnie koszty te musi ponieść autor artykułu. Dla krajów, uczelni i naukowców z krajów mniej zamożnych oznaczać to może barierę dostępu ${ }^{25}$. Jak to się ma do zasady sprawiedliwości?

Wśród argumentów za otwartym dostępem wymieniano także zwiększenie ich wpływu i widoczności, w tym cytowań. Niedawne studium nie potwierdza, aby czasopisma w otwartym dostępie miały znaczną przewagę $\mathrm{w}$ tym zakresie nad czasopismami tradycyjnymi ${ }^{26}$.

Podzielam wątpliwości co do otwartego dostępu. Nauka nie jest dobrem wolnym - kosztuje, i to sporo. Otwarty dostęp promują ci, którzy na nim zarabiaja, w szczególności międzynarodowi wydawcy.

Jedną z najpoważniejszych negatywnych konsekwencji otwartego dostępu jest zjawisko drapieżnych czasopism ${ }^{27}$, o których będzie mowa w kolejnej części artykułu.

Nie ma zapewne odwrotu od ruchu otwartego dostępu. Ważne jest zatem, aby ograniczać bariery dostępu autorów z mniej zamożnych krajów oraz dbać o jakość. Pewnym kompromisem jest także model hybrydowy, w którym niektóre artykuły są dostępne za darmo.

\footnotetext{
25 Jajszczyk (2020).

${ }^{26}$ Basson, Blanckenberg, Prozesky (2020).

27 Beall (2013).
} 


\section{DRAPIE ŻNE CZASOPISMA - KONIECZNE ZWALCZANIE PATOLOGII}

Skrajnym przypadkiem patologii w zakresie czasopism naukowych sa tzw. drapieżne czasopisma (ang. predatory journals). Takim mianem określa się czasopisma, których „polityka publikacyjna charakteryzuje się natarczywym zachęcaniem potencjalnych autorów do publikacji, brakiem przejrzystego składu redakcji czasopisma, ukrytą siedzibą wydawcy/ redakcji oraz nierzetelnym procesem recenzyjnym wyrażającym się $\mathrm{w}$ braku przestrzegania należytych standardów”28. Autorzy artykułu na ten temat w „Nature” z 2019 r. uzgodnili następującą definicję: „Drapieżne czasopisma i wydawcy przedkładają własny interes nad wiedzę, charakteryzują się fałszywą lub mylną informacja, odstępstwem od najlepszych praktyk edytorskich i wydawniczych, brakiem przejrzystości i/lub stosowaniem agresywnych i niewybrednych praktyk narzucania się"29. Drapieżne czasopisma wykorzystuja model otwartego dostępu: czasopismo jest dostępne za darmo, ale autorzy płacą za opublikowanie swojego artykułu.

Niestety, praktyki takie sa negatywną konsekwencją wzrostu znaczenia publikacji w czasopismach (publish or perish), upowszechnienia opłat za publikacje w międzynarodowych czasopismach, co rodzi niekiedy pokusę wysokiego zarobku poprzez nieetyczne praktyki.

Z takimi patologiami trzeba zdecydowanie walczyć. Nie powinno nas uspokajać to, że artykułów w drapieżnych czasopismach „nikt nie czyta” i w konsekwencji nie sa one cytowane ${ }^{30}$. Niezbędne jest upublicznianie nazw czasopism nieprzestrzegających zasad etyki. Od lat powstają listy takich czasopism, zapoczatkowane przez bibliotekarza Jeffreya Bealla.

Vít Macháček i Martin Srholec, ekonomiści z Pragi, zidentyfikowali w bazie Scopus 324 czasopisma z listy potencjalnie drapieżnych czasopism stworzonej wcześniej przez Bealla. W latach 2015-2017 czasopisma te opublikowały około 164 tysięcy artykułów, co stanowiło około 2,56\% artykułów indeksowanych w bazie Scopus w tym okresie, przy czym odsetek ten jest zróżnicowany pomiędzy krajami ${ }^{31}$.

Na problem drapieżnych czasopism w Polsce zwracano uwagę od dawna, między innymi w 2018 r. zabrał głos dyrektor Narodowego Centrum Nauki. Przykładem upubliczniania tego problemu może być artykuł niestrudzonego tropiciela patologii w polskiej nauce z tegorocznego numeru „Forum Akademickiego" ${ }^{2}$. W artykule opisano czasopismo z zakresu nauk ekonomicznych: „European Resarch Studies Journal”, założone w 1998 r. przez prof. Thalassinosa z Uniwersytetu w Pireusie, obecnie wydawane w otwartym dostępie przez International Strategic Management Association. Czasopismo było indeksowane

\footnotetext{
28 Burdzik (2017): 131.

${ }^{29}$ Grudniewicz et al. (2019): 211.

30 Brainard (2020).

31 Macháček, Srholec (2021).

32 Wroński (2021).
} 
w bazie Scopus w latach 2008-2017, od 2018 r. nie jest, nigdy nie było indeksowane w JCR, nie ma impact factor. Na polskiej liście ministerialnej ma 100 pkt, co skłoniło wielu polskich autorów do publikowania w tym czasopiśmie. W roku 2020 polscy badacze stanowili ponad 80\% autorów kolejnych numerów. Jak łatwo sprawdzić na stronie czasopisma, w pierwszym numerze z roku 2021 na 76 artykułów (!) aż 71 jest autorstwa polskich naukowców. Niezrozumiałe jest utrzymanie tak wysokiej punktacji dla tego czasopisma na liście z 2021 r. - to kolejny przykład słabości polskiego biurokratycznego systemu list czasopism.

Bardzo ważne jest informowanie o problemie i ostrzeganie autorów, którzy niekiedy nieświadomie mogą wpaść w szpony drapieżnych wydawców ${ }^{33}$. Ważne jest, aby uczelnie czy instytuty badawcze nie finansowały takich publikacji z pieniędzy publicznych (za opublikowanie artykułu w omawianym czasopiśmie pobierano opłatę około 650 euro $^{34}$ ), aby nie przyznawano za nie nagród itd. Walka z tą patologia, jak z każda, nie jest łatwa, ponieważ drapieżne czasopisma stale dostosowują się do nowych okoliczności ${ }^{35}$.

Nie należy jednak wylewać dziecka z kapiela, a tym groziłoby zakwestionowanie znaczenia publikacji w międzynarodowych czasopismach ze względu na drapieżne czasopisma. One stanowią margines, z którym należy stanowczo walczyć. Walka z patologią leży w interesie naukowców, uczelni, państwa finansującego naukę i samych wydawców. Samo środowisko naukowców powinno być przy tym najbardziej zainteresowane „,samooczyszczeniem się”, bez czekania wyłącznie na interwencję państwa, skądinąd też potrzebną (lista czasopism, ewaluacja).

\section{PRZYSZŁOŚĆ CZASOPISM NAUKOWYCH}

Czasopisma naukowe będą istniały, trudno bowiem wyobrazić sobie naukę bez tego podstawowego kanału komunikacji. Równocześnie czeka je wiele wyzwań, wobec zmieniającego się świata.

Należy się spodziewać pogłębiania się zróżnicowania między najbardziej prestiżowymi, elitarnymi, międzynarodowymi czasopismami w języku angielskim, z jednej strony, a znacznie liczniejszymi czasopismami o bardziej lokalnym zasięgu, w tym w językach narodowych. Potrzebne sa jedne i drugie, a systemy ewaluacji powinny promować większą równowagę w tym zakresie.

Pożądane byłoby ograniczenie negatywnych konsekwencji kultury publish or perish przez osłabienie zastosowania list czasopism, z przypisanymi im punktami, do oceny indywidualnych osiagnięć naukowców. Zdecydowanie ważniejsze powinno być to, co naukowiec odkrył, co jego badania wniosły do zasobów wiedzy, niż to, ile zdobył punktów.

\footnotetext{
${ }^{33}$ Krajewski, Modrzewska (2015).

34 Wroński (2021): 54.

35 Grudniewicz et al. (2019): 212.
} 
Czasopisma naukowe są w zdecydowanej większości związane z określonymi dyscyplinami, choć nie wydaje się zasadne sztywne i biurokratyczne określanie tych granic. Równocześnie można się spodziewać rozwoju także czasopism wielodyscyplinarnych, publikujących wyniki badań z różnych dyscyplin, a tym samym lepiej odpowiadających na realne problemy świata, których nie da się „zaszufladkować” według dyscyplin. Sukces „Nature” czy „Science” jest tutaj wymownym przykładem.

Prawdopodobna wydaje się ewolucja w kierunku krótszych, syntetycznych artykułów. Być może także w naukach społecznych i humanistycznych, w których jesteśmy dotąd przyzwyczajeni do standardu arkusza wydawniczego, będziemy skłonni zaakceptować standardy z innych dziedzin nauki, w których w bardziej syntetycznej formie przedstawiane są wyniki badań.

Gdyby czasopisma naukowe ewoluowały w kierunku krótszych tekstów, prezentujących syntetycznie wyniki badań (jak w „Nature” albo „Science”), miejscem na bardziej „tradycyjną” formę komunikacji naukowej pozostać mogłyby monografie. Należy bowiem przyjąć, że czasopisma naukowe nie wyeliminują książek, monografii, które odgrywają kluczową rolę w komunikacji naukowej w naukach społecznych i humanistycznych.

Jestem przekonany, że „Ruch Prawniczy, Ekonomiczny i Socjologiczny” będzie umacniał swoja pozycję wśród najlepszych polskich czasopism.

Bäcker, R. (2019). Politologia warta najmniej? Forum Akademickie 26(9): 13.

Basson, I., Blanckenberg, J.P., Prozesky, H. (2021). Do open access journal articles experience a citation advantage? Results and methodological reflections of an application of multiple resources to an analysis by WoS subject areas. Scientometrics 126: 459-484.

Beall, J. (2013). Predatory publishing is just one of the consequences of gold open access. Learned Publishing 26(2): 79-84.

Brainard, J. (2020). Articles in "predatory" journals receive few or no citations. Science 367(6474): 129.

Breczko, S. (2016). Książka naukowa - między środowiskiem akademickim a branżą wydawniczą. Nauka i Szkolnictwo Wyższe 2(48): 95-117.

Burdzik, T. (2017). Drapieżne czasopisma jako przykład nieetycznego publikowania. Filozofia i Nauka. Studia Filozoficzne i Interdyscyplinarne 5: 131-149.

Drabek, A., Bemke-Świtilnik, M. (2020). O wykazach, punktozie i polskich czasopismach humanistycznych. Forum Akademickie 27(11): 24-27.

Giménez-Toledo, E., Román-Román, A. (2009). Assessment of humanities and social sciences monographs through their publishers: a review and a study towards a model of evaluation. Research Evaluation 18: 201-213.

Godin, B. (2017). O początkach bibliometrii. Nauka i Szkolnictwo Wyższe 1(49): 19-46.

Gorynia, M. (red.) (2019). Ewolucja nauk ekonomicznych. Jedność a różnorodność, relacje do innych nauk, problemy klasyfikacyjne. Warszawa.

Grudniewicz, A. et al. (2019). Predatory journals: no definitione, no defence. Nature 576: 210-212.

Hintz, M., Nęcka, E., Prostak, R., Welfe, A. (2019). Jak powstał nowy wykaz czasopism naukowych. Forum Akademickie 26(11): 28-31.

Jajszczyk, A. (2020). Spór o otwarty dostęp. Forum Akademickie 27(9): 44-46.

Kokowski, M. (2018). Podstawowe zastrzeżenia wobec projektu i uchwalonej Ustawy 2.0 vel Konstytucji dla nauki. Studia Historiae Scientiarum 17: 453-476.

Krajewski, P., Modrzewska, M. (2015). Ciemna strona open access - naukowcy w szponach drapieżnych wydawców. Forum Bibliotek Medycznych 8(2): 213-227. 
Kulczycki, E. (2017). Punktoza jako strategia w grze parametrycznej w Polsce. Nauka i Szkolnictwo Wyższe 1(49): 63-78.

Kulczycki, E. (2019). Władza ewaluacyjna a przekształcenia komunikacji naukowej, [w:] J.M. Brzeziński, T. Wallas (red.), Uniwersytet XXI wieku. Między Uniwersytetem Humboldta a uniwersytetem badawczym. Poznań: 159-181.

Kulczycki, E., Korytkowski, P. (2019). Researchers publishing monographs are more productive and more local-oriented. Scientometrics 125: 1371-1387.

Kulczycki, E. et al. (2020). Multilingual publishing in the social sciences and humanities: a seven-country European study. Journal of the Association for Information Science and Technology 71(11): 1371-1385.

Kwiek, M. (2019a). Ekonomia prestiżu akademickiego. Ilościowe ujęcie najlepszych czasopism na przykładzie dziedziny badań nad szkolnictwem wyższym. Nauka i Szkolnictwo Wyższe 1/2(53/54): 11-46.

Kwiek, M. (2019b). Internacjonaliści i miejscowi - międzynarodowa współpraca badawcza w Polsce na mikropoziomie indywidualnych naukowców. Nauka i Szkolnictwo Wyższe 1/2(53/54): $47-105$.

Macháček, V., Srholec, M. (2021). Predatory publishing in Scopus: evidence on cross-country differences. Scientometrics, published online 07 February 2021.

Melosik, Z. (2016). Wskaźnikowanie człowieka i rzeczywistości jako forma sprawowania władzy. Przegląd Pedagogiczny 2: 243-253.

Sivertsen, G. (2017). Finansowanie oparte na publikacjach - Model norweski. Nauka i Szkolnictwo Wyższe 1(49): 47-59.

Skoczeń, B. (2019). Pierwsze kroki ku ewaluacji jakości nauki. Forum Akademickie 26(11): 32-33.

Szpunar, M. (2019). Kwantyfikacja rzeczywistości. O nieznośnym imperatywie policzalności wszystkiego. Zeszyty Prasoznawcze 62(3): 95-104.

Tokarczuk, O. (2020). Czuły narrator. Kraków.

Van Dalen, H.P. (2021). How the publish-or-perish principle divides a science: the case of economists. Scientometrics 126: 1675-1694.

Wilkin, J. (2020). Znaczenie uniwersytetów w epoce postprawdy, [w:] B. Fiedor, M. Gorynia, E. Mączyńska, Nauki ekonomiczne i wyzwania współczesności. Fundamentalne problemy w teorii i praktyce. Warszawa: 83-96.

Wroński, M. (2021). Jak zapełnić sloty. Forum Akademickie 28(2): 53-54.

Wróblewski, A.K. (2018). Zatruty prezent na stulecie niepodległości Polski. PAUza Akademicka 435: 2.

\section{CURRENT ISSUES FACING SCIENTIFIC JOURNALS IN POLAND}

\section{Sum mary}

Scientific journals are and probably will remain the key research communication channel. In the social sciences and humanities, journals will not eliminate or marginalize books (monographs). Although measuring research results by means of lists and points is probably necessary, attempts should be made to at least counteract the downsides of running after points and impactitis. Publishing in prestigious international journals in English is important for participation in international research, but good journals in Polish should also be supported, especially those focused on the social sciences and humanities and addressing issues associated with culture and society. There are no strong arguments for the bureaucratic assigning of scientific disciplines to journals on the Minister's list, and multidisciplinary journals should be supported. Open access to scientific journals has advantages, but it raises concerns about equal access of authors from poorer countries, and about quality. The joint efforts of researchers, publishers and governments are needed to fight against the pathology of predatory journals. Scientific journals in the field of the social sciences and humanities could accept shorter, concise texts, taking the role of books in these sciences into account.

Keywords: scientific journals; research evaluation; lists of journals; economic sciences; Poland 
